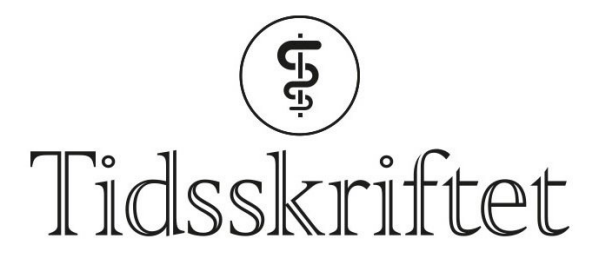

DEN NORSKE LEGEFORENING

\title{
Kjønnsforskjeller i overlevelse ved blærekreft
}

FRA ANDRE TIDSSKRIFTER

JON MAGNUS HAGA

Tidsskriftet

Dødeligheten ved blærekreft er ulik for kvinner og menn. Forskjeller i tumorstadium ved diagnosetidspunkt kan forklare mye av forskjellen, viser en norsk studie.

I en norsk studie som nylig er publisert i European Journal of Cancer, ble langtidsoverlevelse hos om lag 15 ooo pasienter diagnostisert med blærekreft i perioden 1997-2011 undersøkt basert på data fra Kreftregisteret (1). Dødelighet knyttet til blærekreft var høyere hos kvinner enn hos menn, men kun de to første årene etter at diagnosen ble stilt. Senere var dødeligheten høyere hos menn.

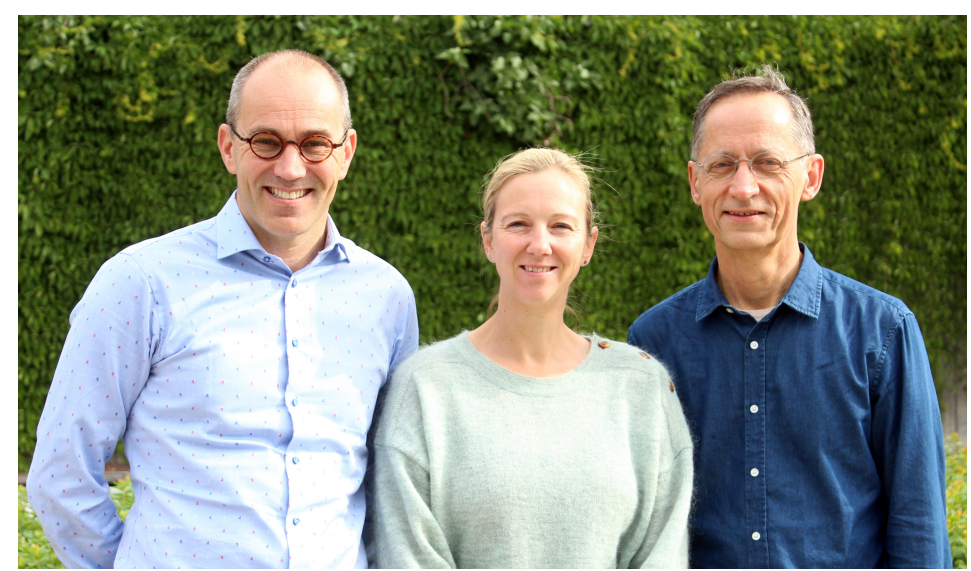

Erik Skaaheim Haug (t.v.) er urolog ved Sykehuset $i$ Vestfold og leder for Helsedirektoratets gruppe for handlingsprogram for blare- og urotelkreft. Bettina Kulle Andreassen og Tom Kristian Grimsrud (t.h.) er forskere ved Kreftregisteret. Alle er involvert i flere forskningsprosjekter om blcerekreft basert på registerdata fra Kreftregisteret. Foto: Elisabeth Jakobsen/Kreftregisteret

- Disse funnene er ikke overraskende, men det er første gang forskjellen er tallfestet, sier Erik Skaaheim Haug, som er urolog ved Sykehuset i Vestfold og medforfatter av studien. Kjønnsforskjellene var i hovedsak knyttet til at kvinner oftere fikk påvist en mer avansert kreftform ved diagnosetidspunktet enn menn, men også andre faktorer spiller inn, sier Haug. 


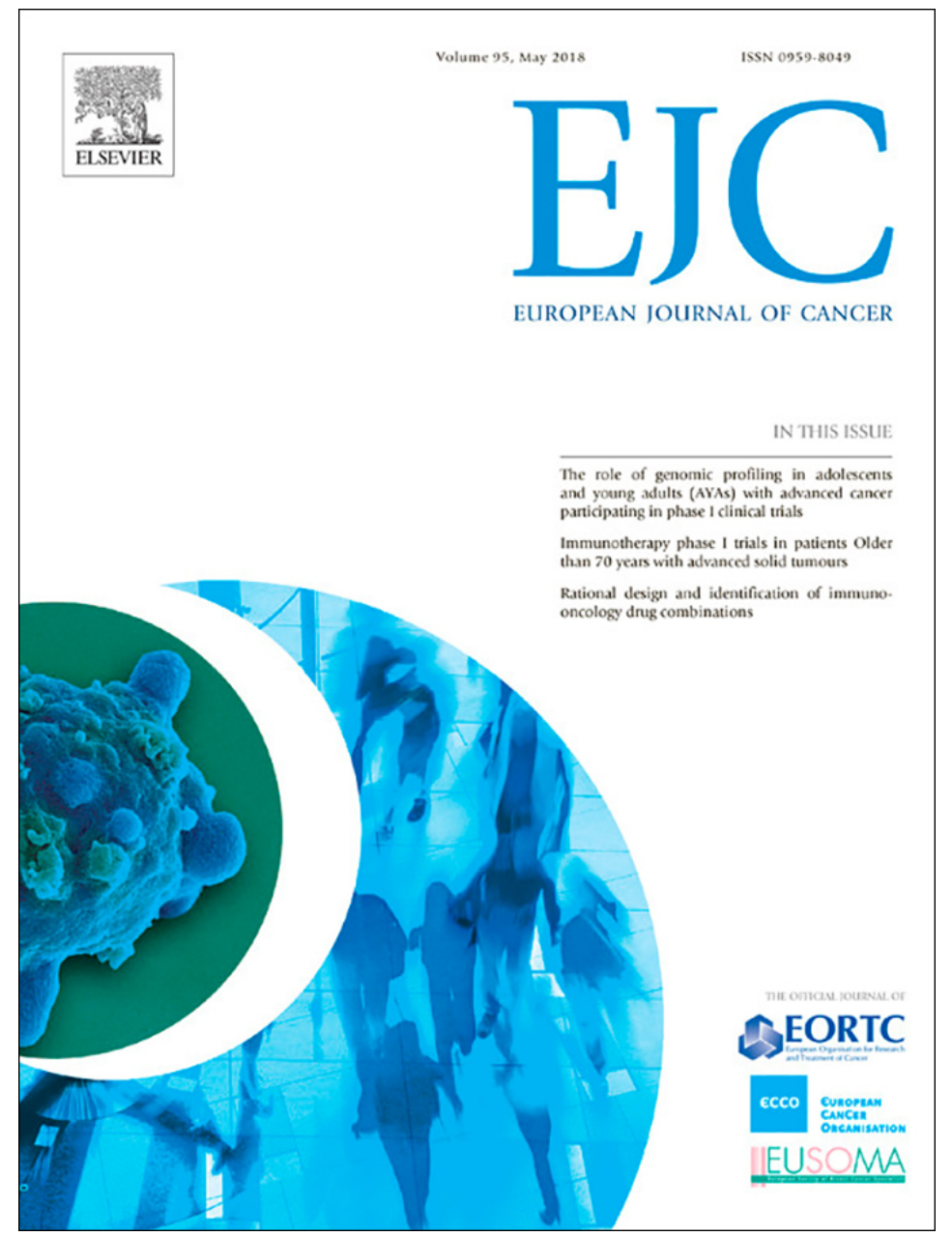

Forsiden, European Journal of Cancer

- Leger må være oppmerksom på at urinveisinfeksjoner som ikke gir seg etter antibiotikabehandling, kan være tegn på blærekreft, sier Bettina Kulle Andreassen, forsker ved Kreftregisteret og leder for det aktuelle forskningsprosjektet. Hun opplyser at et nytt nasjonalt handlingsprogram for diagnostikk, behandling og oppfølging av blærekreft vil bli publisert høsten 2018.

\section{LITTERATUR:}

1. Andreassen BK, Grimsrud TK, Haug ES. Bladder cancer survival: Women better off in the long run. Eur J Cancer 2018; 95: 52 - 8. [PubMed][CrossRef]

Publisert: 17. september 2018. Tidsskr Nor Legeforen. DOI:10.4045/tidsskr.18.0500

(C) Tidsskrift for Den norske legeforening 2020. Lastet ned fra tidsskriftet.no 